\title{
Green Building Certification of Urban Public Railway Transport Systems for Sustainable Cities
}

\author{
E. DURSUN, S.VARBAK NESE and B. KILIC
}

\begin{abstract}
The increasing consumption of energy and the greenhouse-gas emissions are challenges in the transport and building sectors. Compared to the other transportation types public railway transport systems are the most energy efficient regarding carbon footprint. Modern urban railway public transport systems have the significant advantages of large passenger capacity, punctuality, safety, going green in the urban environment and reducing carbon footprint, is a scientific consensus. However, the energy demand for railways are increasing in proportion to passenger load, require implementing innovative solutions for optimizing the energy consumption and reducing carbon emission. Leadership in Energy and Environmental Design (LEED) is a building rating system used worldwide. The credit categories of the LEED consist of seven different topics from the Energy and Atmosphere to Materials and Resources. In this study, the LEED certification application to railway station and facilities will be discussed mainly energy efficiency criteria.
\end{abstract}

Index Terms-Railway buildings, energy efficiency, green building certification, LEED

\section{INTRODUCTION}

A $S$ THE TRANSPORTATION sector has a significant share in the economy of each country, there is severe competition among the different modes of transport in the European Union countries [1]. Also, urban transport is the source of one-fourth of the $\mathrm{CO} 2$ emissions in the transport sector and $7 \%$ of the total greenhouse gas emissions [2]. Road transport has adverse effects such as traffic congestion,

ERKAN DURSUN, is with Department of Electrical and Electronics Engineering of Marmara University, Istanbul, Turkey, (e-mail: erkandursun@marmara.edu.tr).

\section{(iD) https://orcid.org/0000-0002-7914-8379}

SECIL VARBAK NESE, is with Department of Electrical and Electronics Engineering of Marmara University, Istanbul, Turkey, (e-mail: secil.varbak@marmara.edu.tr).

(iD) https://orcid.org/0000-0002-1118-5085

BEYHAN KILIC, is with Department of Electrical and Electronics Engineering of Yildiz Technical University, Istanbul, Turkey, (e-mail: beykilic@yildiz.edu.tr).

iD https://orcid.org/0000-0002-8438-8369

Manuscript received October 20, 2019; accepted November 24, 2019. DOI: $\underline{10.17694 / \text { bajece. } 649183}$ dependence on fossil fuels, the environment, noise, accident rate $[1,2]$. For this reason, it is vital to increase the number of integrated, accessible and environmentally friendly transport systems to reduce carbon emissions and improve urban living conditions [2]. Railway transport attracts more attention than road transport. In this context, the European Union countries aim to increase the share of railway transport by $10 \%$ until 2020 and as a result, to reduce fuel emissions by $50 \%$ [1].

Today transportation is mostly provided by vehicles that use petroleum products as fuel. In railway transportation, it is thought that dependency on petroleum products is decreasing as electric motors are used. On the other hand, in many countries, electricity generation is based on oil and coal-based generation $[3,4]$. According to the data of 2016, more than $33 \%$ of passengers in Japan preferred to use railway transportation, while the number of rail passengers in China was 16.1 billion in urban and 2.8 billion in inter-city. This increased utilization not only increases the infrastructure load, but it also brings with it the requirements of innovation and change [5]. There is also a competitive environment due to the ever-increasing environmental performance and energy costs of other types of transportation, such as the automotive sector. In this competitive environment, it is necessary to reduce energy use while increasing the quality of rail transport services [6].

LEED is the most common international certification system for sustainable buildings with goals such as energy conservation, rational water use, developing a regional project area, improving interior building quality, conscious use of building materials and innovation [7]. Globally, $1.9 \%$ of transportation final energy claims and $4.2 \%$ of $\mathrm{CO} 2$ emissions from the transport sector in 2015 were due to railway transport [8]. In this context, the U.S. Green Building Council (USGBC) and Green Business Certification Inc. (GBCI) have announced a new LEED pilot rating system for green building to cover transit systems around the world: LEED V4 Operations and Maintenance $(\mathrm{O}+\mathrm{M})$ : Transit. The new rating system is developed a LEED certification for the design, construction and operation of transport organizations including facilities and stations with a holistic approach. The new performance platform will simplify monitoring the data in railway stations about water, energy usage, waste production, transportation and passenger experience in totally five categories. The LEED management committee, commissioning authority that approves main changes in the technical requirements, validated the new pilot rating system 
[9]. In this study, the LEED certification application to railway station and facilities will be discussed mainly energy efficiency criteria.

\section{LEED V4 O+M: TRANSIT CERTIFICATION FOR RAILWAY BUILDINGS AND STATIONS}

Railway transit systems reduce traffic congestion, emissions, and energy used compared to other transit modes; it improves inherently sustainability of cities. However, the energy demand for railways is increasing in proportion to passenger load, require to implement innovative solutions for optimizing the energy consumption and reducing carbon emission [10]. The USGBC launched a new LEED pilot system to meet the particular requirements of transport systems. This pilot system focuses on the transportation buildings, like passenger stations, depot areas, terminal buildings [11]. Especially railway facilities have high energy usage, water usage, a waste production which affects people lives and environment [12]. The railway station buildings and facilities can take the opportunity to become energy efficient, cost-effective and environmental friendly by implementing LEED v4 O+M: Transit. This pilot system is interpreted as in collaboration with the specific needs of metro stations and facilities LEED certification. It aims at enabling metro stations performance. LEED v4 O+M: Transit can be used to monitor and compare performance across the transit system. The description below and in the certification section outlines how to document performance, identify areas for improvement and certify to LEED. To confirm, project teams must complete two components made up of the LEED v4 O+M rating system [13]. The Arc-online performance platform addresses the need for existing buildings, stations through continuous data uploads, real-time analysis. Even though a building has not certified yet, can participate in the platform, record incremental improvements and performance in five key subcategories. In this context, LEED v4 O+M: Transit will allow transport facilities and stations will enable monitoring and measuring performance, make improvements, score performance and to benchmark efficiencies. This rating system promotes the railway operators reduce their environmental footprint and also create awareness on sustainability. Railway operators can reduce their environmental footprint, while also create awareness on the importance of sustainability and opportunities in minimizing greenhouse gas emissions [14].

Except for the primary structures as rail lines, tunnels, bridges, and tracks, railway systems own to different facilities like railway passenger stations, office buildings, depot areas, maintenance shop, control rooms, traction substations. Inherently, the multi-layered of technical and organizational processes take place at railway facilities, especially railway stations. The challenge is the interdependence of railway subsystems of complex railway systems to ensure sustainable operation, safety, security and environmental sensitivity. The complex railway systems especially facilities require an integrated application of intelligent technologies and operational strategies to reduce energy consumption and carbon emission. Railway passenger stations are the central component of railway networks, which thousands passenger board and alight complex areas have passenger platforms, concourses, ticket offices. To maintain safe and secure passenger flow in the system is a crucial issue. While organizing the station facilities and infrastructure to ensure a smooth flow of passengers, especially in peak times, energy efficiency, environment-friendly, and sustainable solutions are required [15].

\section{THE ACHIEVED LEED CERTIFICATION AT METRO STATIONS AROUND THE WORLD}

The LEED v4 O+M: Transit gives an opportunity to address measuring the performance of facilities of metro stations. Railway operators can reduce their energy consumptions, while also drawing the attention to the importance of sustainability in the public transportation sector [16]. Transportation generated $14 \%$ of all greenhouse gas emissions in 2010. In the United States, $27 \%$ of the greenhouse gas emissions in 2015 were due to transportation. There are more than 160 cities in the world that have developed metro networks, most of which are in Asia and Europe. In a day, more than 160 million passengers travel on metro lines, and only more than 80 million passengers travel on metros in Asia [17].

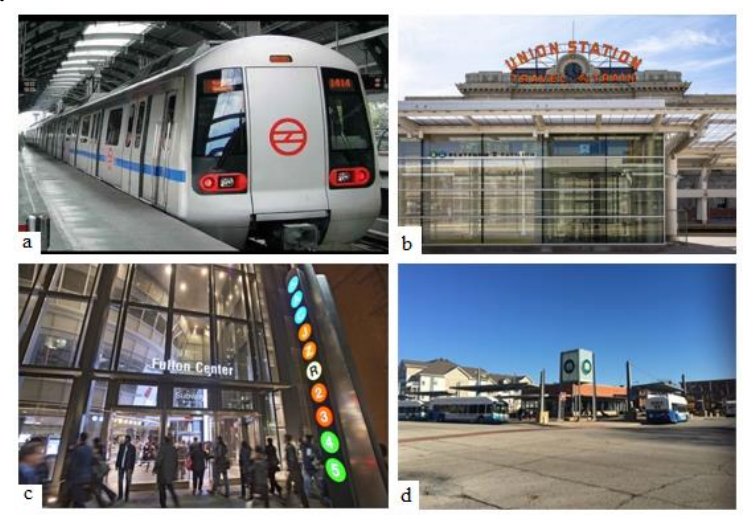

Fig. 1. Some examples of the LEED-certified railway: Delhi Metro Rail Station(a), Denver Union Station Transit Center(b), The Fulcon Center(c), Rock Island District Station(d) [18-21].

Some examples of the LEED-certified railway station buildings all over the world are shown in Fig.1. The first metro is achieving the pilot, LEED v4 O+M: Transit certification, for Delhi NCR metro stations in India, is Delhi Metro Rail Corporation (DMRC). LEED v4 O+M: Transit will allow transport facilities and stations will allow monitoring and measuring performance, make improvements and score performance and to benchmark efficiencies. The Arc performance platform provides data flow from stations and benchmarking interstations, improvements about five key categories [18]. The Sound Transit's light rail facility has 
achieved the LEED Gold certification for green implementations in the construction of the Angle Lake Station in the USA. The station has built environmentally sustainable specifications. 60-solar panel integrated into the platform roof generates energy up to $18 \mathrm{kWh} /$ year. The escalators speed reduces if no passengers. $50 \mathrm{~kW}$ solar panels installed on the pedestrian walkway. Four charging stations are installed in the garage. Recycled material that not contains toxic chemicals were used for construction. The station lightings energy consumption reduced by LEDs [22]. The Sound Transit wants to obtain LEED Silver certification for future maintenance facilities [23]. Illinois district metro station has achieved LEED gold certification. The station implemented sustainable applications like PV roof, sensor-fitted lighting [24]. The Metropolitan Transportation Authority has gained LEED Silver rating for the Fulton Center in Manhattan which is the first underground station. Some applications were realized in the main categories as energy efficiency, water usage. More than $25 \%$ energy savings were achieved compared to baseline consumption. The Fulton Center provides energy from renewable sources in $50 \%$ rate. The other measures are using daylighting reducing electricity consumption, using low-flow plumbing fixtures. The Denver Union Station Transit Center serves local and regional buses, free MetroRide and MallRide buses, commercial Amtrak and commuter light rail. 25\% decrease in energy costs and 35\% decrease in water usage were observed. Also, $92 \%$ construction waste rate has reached the landfill site [25]. Fulton Center on Broadway has LEED Silver certification. The Metropolitan Transportation Authority has achieved $25 \%$ energy saved and $40 \%$ reduction in water usage with low-flow plumbing fixtures by Fulton Center according to similar constructions. Also, $50 \%$ of energy is supplied from renewable sources. In addition to this, electricity usage is decreased using daylight by iconic oculus [26, 27]. Metro downtown Rock Island District Station has LEED gold certification. The solar panel integrated roof, sensor-fitted lighting and the re-use of rainwater systems are used in the station as sustainability features [18]. Canada LEED certification program launched for the building design, construction, and operation processes [23]. GO Transit's Pickering station has gained a first LEED Gold rating and provided $60 \%$ energy savings annually. Some of the building's eco-friendly features are listed below: heat pump using, a heat recovery unit, low-flow plumbing fixtures, $45 \%$ more potable water, a waste management plan implemented $80 \%$ construction waste from landfill. In Germany, the railway hub in Kerpen Horrem supplies its energy through solar panels within the scope of Station Green programme. A geothermal system provides clean and sustainable floor heating at stations [28]. In England, Accrington railway station has a non-heated hall to take advantage of solar gain. Other environmentalfriendly features like rainwater harvesting, solar hot water generation and solar photovoltaic technology applied for the energy conservation [29]. In Hong Kong, The Mass Transit Railway Corporation (MTR) serves over seven million people. At the main passenger terminal, 73 escalators and 8 moving walkways were installed when not in use automatically slow down to reduce electricity consumption and, when the built-in radar sensors detect a passenger, it will accelerate. Depending on passenger volumes, escalators and moving walks with this feature can save up to $60 \%$ of the energy consumed. 33 escalators are installed to reduce power consumption and regenerate electricity with the weight of the passengers the steps down, working as a generator [30].

\section{ENERGY EFFICIENCY OPPORTUNITIES FOR RAILWAY TRANSPORT SYSTEMS AND METRO STATIONS}

Railways are a vital mode of passenger transportation for both urban and intercity throughout the world. As large-scale public constructions, railway stations are massive structures with high windows and large floor spaces, long platforms, a high ratio of walls, high circulation of people, and have the oversized technical equipment, like escalators, lifts, HVAC systems, lightings. Railway stations also have long operation hours [31]. The oversize of the railway network leads to significant resource consumption. Railway systems' energy consumption can divide into two major categories. The first one is the construction consumptions that consists of train lines, facilities, stations, technical equipment, and trains and after construction process, cannot be changed this consumption. It is important to highlight the decisions during the design process, the construction of infrastructure, trains, and technical systems are hard to change afterward. Therefore, the decision makers should take into considering the environment and energy with a future vision conceptually. The energy consumption during construction of facilities is not covered in this field of research. The second is the whole railway systems energy consumptions that divided into traction of trains and non-traction or auxiliary uses. Traction energy is consumed by running trains while non-traction energy is consumed for the stations, infrastructure facilities, train maintenance workshops, offices. Traction energy is not within the scope of this study. There is an enormous potential for promoting efficiency in non-traction areas of railway facilities, stations, and offices (Table I) [32].

TABLE I

ENERGY SAVING POTENTIAL IN STATIONS AND CONCESSIONS

\begin{tabular}{|l|l|l|}
\hline \multirow{2}{*}{ Lighting } & $\begin{array}{l}\text { Recommended efficiency } \\
\text { measure }\end{array}$ & $\begin{array}{l}\text { Subsystem saving } \\
\text { potential }\end{array}$ \\
\hline \multirow{3}{*}{ Heating and cooling } & Intelligent control & $10-30 \%$ \\
\cline { 2 - 3 } & $\begin{array}{l}\text { Replacement of less efficient } \\
\text { lighting }\end{array}$ & $10-40 \%$ \\
\cline { 2 - 3 } & $\begin{array}{l}\text { Intelligent control including } \\
\text { temperature setting }\end{array}$ & $10-20 \%$ \\
\cline { 2 - 3 } & Insulation of roof and wall & $10-30 \%$ \\
\cline { 2 - 3 } & Renewal of installation & $20 \%$ \\
\hline \multirow{2}{*}{ Powered equipment } & $\begin{array}{l}\text { Newern heat pumps (A+) } \\
\text { intelligent control }\end{array}$ & Up to $30 \%$ \\
\hline Concessions/shops & $\begin{array}{l}\text { Targets and energy audits built } \\
\text { into contracts }\end{array}$ & $10-40 \%$ \\
\hline
\end{tabular}


In the study [32], railway station buildings including passenger boarding platforms, concourse area. Railway stations can be divided into three main groups: underground, surface and tunnel type. The energy consumptions of the railway stations vary from each other because of different kinds of equipment and features. Divisions of railway systems into subsystems ensure much better the understanding of total and partial energy consumption. Thus, energy consumptions of components or subsystems can be determined. Realizing gains in energy efficiency and emission reduction requires the holistic energy efficiency measures. The system's total energy consumption identified by the division of the systems to subsystems or components.

Railway stations have enormous energy consumption compared with other large public buildings. According to an energy survey, massive stations energy consumption is about $214\left(\mathrm{kWh} / \mathrm{m}^{2}\right)$ per year; compared with similar buildings. Accordingly, the station buildings have high-efficiency opportunities for renovating existing buildings. HVAC equipment contributes to $59 \%-67.9 \%$ of all consumption in underground stations [33]. The most significant energy loads were identified as HVAC and lighting systems in underground stations may represent up to $60 \%$ of the total consumption [34]. The factors that affect energy consumptions of HVAC systems in the rail facilities should be investigated as temperature setting values and programmable specifications. According to local temperature, HVAC systems' duty cycle must be determined for energy efficiency measures. An energy audit should be accomplished for the lighting and HVAC systems at the facility. Variable Frequency Driven (VFD) HVAC systems can ensure better energy efficiency by $30 \%$ [35]. The cooling demand can be reduced by incremental temperature changes from station entrance hall to platform. The exhaust fans can be set according to the outside temperature. If the external environment temperature is lower than $22^{\circ} \mathrm{C}$, exhaust fans can blow out the station, air so that cool outer air to be pulled into the station through the entrance. This application reduces energy consumption. The incoming train to the underground station circulates cooled air between the station and the tunnel. The train forces cooled air to the tunnel [36]. This is defined as the piston effect. Platform screen door reduces this effect. Energy consumption of metro systems is shown in Fig.2. Traction consumptions $40 \%$, HVAC is $30 \%$, elevator and lifts consumes $12 \%$. For the lighting system $10 \%$. Finally, $4 \%$ for the drainage system [37].

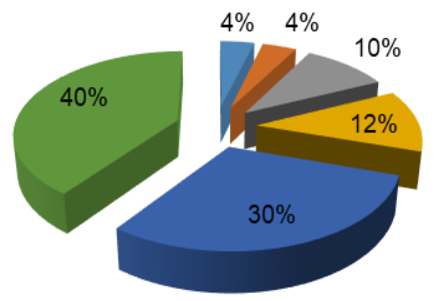

- Other Systems
- Drainage System
- Lighting System
-Elevators and lifts
-HVAC
Traction

Fig. 2. General energy consumption ratios of metro systems [37].

\section{ISTANBUL URBAN RAILWAY SYSTEMS}

Istanbul is the most significant city in Turkey which has over 15 million populations. The Metro Istanbul Corporation, the most prominent operator of urban railways in Turkey, has 174 $\mathrm{km}$ of railway lines and transports 1.6 million passengers daily. Electrical energy consumption of The Metro Istanbul Corporation for the 2017 year was 293 million kWh [38]. The on-going new metro line construction's length is $207.6 \mathrm{~km}$. In Istanbul urban area, $270.6 \mathrm{~km}$ railway lines are in project phase [39]. The Istanbul urban lines and stations specifications are summarized in Table II.

TABLE II

ISTANBUL URBAN RAILWAY LINES SPECIFICATIONS [39]

\begin{tabular}{|c|c|c|c|c|c|c|}
\hline Line & $\begin{array}{l}\text { Name of } \\
\text { line }\end{array}$ & $\begin{array}{c}\begin{array}{c}\text { Length } \\
(\mathrm{km})\end{array}\end{array}$ & Stations & $\begin{array}{l}\text { Escalator } \\
\text { number }\end{array}$ & $\begin{array}{c}\text { Lift } \\
\text { number }\end{array}$ & Passenger/day \\
\hline M1A & $\begin{array}{l}\text { Yenikap1- } \\
\text { Atatürk } \\
\text { Airport }\end{array}$ & 19.75 & 18 & 235 & 65 & 400000 \\
\hline M1b & $\begin{array}{l}\text { Yenikap1- } \\
\text { Kirazlı }\end{array}$ & 14.17 & 13 & 135 & 65 & 400000 \\
\hline M2 & $\begin{array}{l}\text { Yenikap1- } \\
\text { Hacıosman }\end{array}$ & 20.6 & 16 & NA & NA & 320000 \\
\hline M3 & $\begin{array}{c}\text { Kirazl1- } \\
\text { Başakşehir }\end{array}$ & 15.9 & 11 & NA & NA & 70000 \\
\hline M4 & $\begin{array}{l}\text { Kadıköy- } \\
\text { Tavşantepe }\end{array}$ & 25.6 & 19 & 259 & 70 & 70000 \\
\hline M5 & $\begin{array}{l}\text { Üsküdar- } \\
\text { Yamanevler }\end{array}$ & 10.6 & 9 & NA & NA & $\begin{array}{l}\text { Recently } \\
\text { commisioned }\end{array}$ \\
\hline M6 & $\begin{array}{c}\text { Levent- } \\
\text { Boğaziçi } \\
\text { University }\end{array}$ & 3.1 & 4 & NA & NA & NA \\
\hline T1 & $\begin{array}{l}\text { Kabataş- } \\
\text { Bağcılar }\end{array}$ & 18.2 & 31 & NA & NA & 320000 \\
\hline F1 & $\begin{array}{l}\text { Taksim- } \\
\text { Kabataş }\end{array}$ & 0.594 & 2 & NA & NA & 35000 \\
\hline T3 & $\begin{array}{l}\text { Kadiköy- } \\
\text { Moda }\end{array}$ & 2.6 & 10 & NA & NA & 1800 \\
\hline $\mathrm{T} 4$ & $\begin{array}{l}\text { Topkap1- } \\
\text { Mescid-i } \\
\text { Selam }\end{array}$ & 14.5 & 22 & NA & NA & 170000 \\
\hline & Marmaray & 13.6 & 5 & NA & NA & $75000 /$ hour \\
\hline
\end{tabular}

NA: currently not available

M1A light metro line initial started up in 1989. This light metro line consists of partially underground, tunnel, surface, and viaduct stations. The energy consumption of LRT line is 63.35 million $\mathrm{kWh}$ in 2015. Since it is the oldest line in Istanbul, the efficiency audit was conducted at one of the tunnel stations. The Bahçelievler station is shown in Fig.3. The station installed power distribution and energy consumption are given in Fig.4 and Fig.5, respectively.

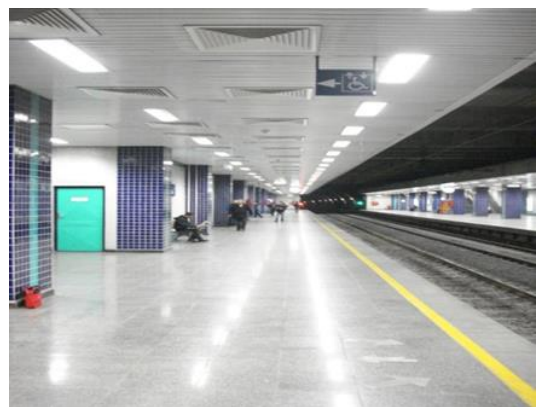

Fig.3. The Bahçelievler tunnel station passenger platform 


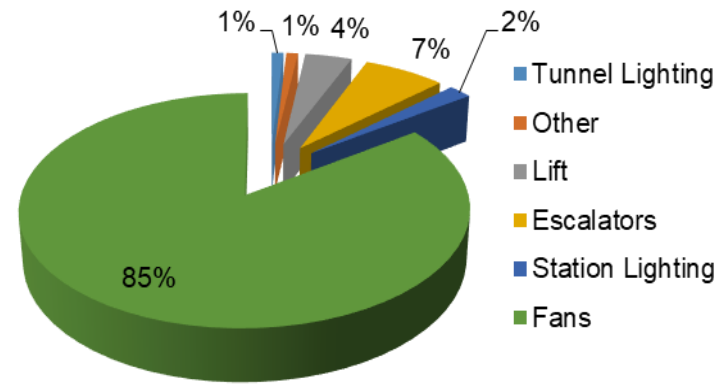

Fig.4. Bahçelievler tunnel station technical equipment installed power $(\mathrm{kW})$ diagram.

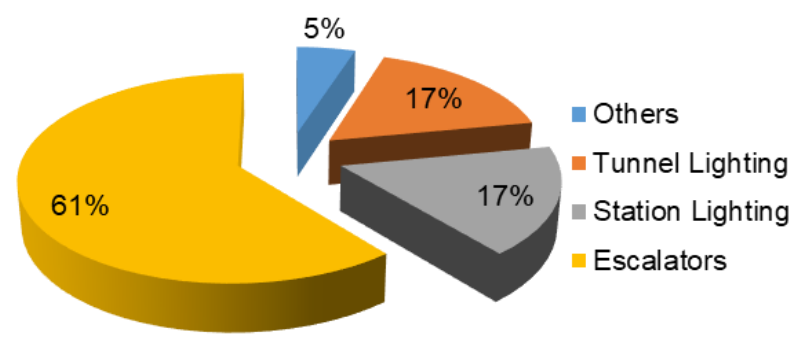

Fig.5. The Atatürk Havalimanı-Yenikapı LRT line Bahçelievler tunnel station monthly energy consumptions [34].
Escalators are one of the most energy consuming systems in underground stations. In the underground stations, the most energy consuming group is HVAC systems [40]. However, in the tunnel type stations, the before and after stations are open stations, HVAC systems are not frequently used because of the piston effect of the trains. The incoming train to the underground station circulates air between the station and the tunnel [36]. Escalators energy consumption can reduce using sensors by $30 \%$ compared to non-sensor escalator [41].

The lighting energy consumption takes the second place. Lighting systems ratio to the installed power is $2 \%$. Because of the lighting system is open 24 hours for security and comfort reasons, energy consumptions of lightings systems rise to $34 \%$. The measurement of escalators and platform lightings are given in Fig. 6, 7, 8 and 9 respectively. The escalators in Bahçelievler station have no sensors, Fig.6. The airport station escalators have motion sensors. However, the airport station is out of the scope of this audit, the measurement is shown here for the benchmarking.

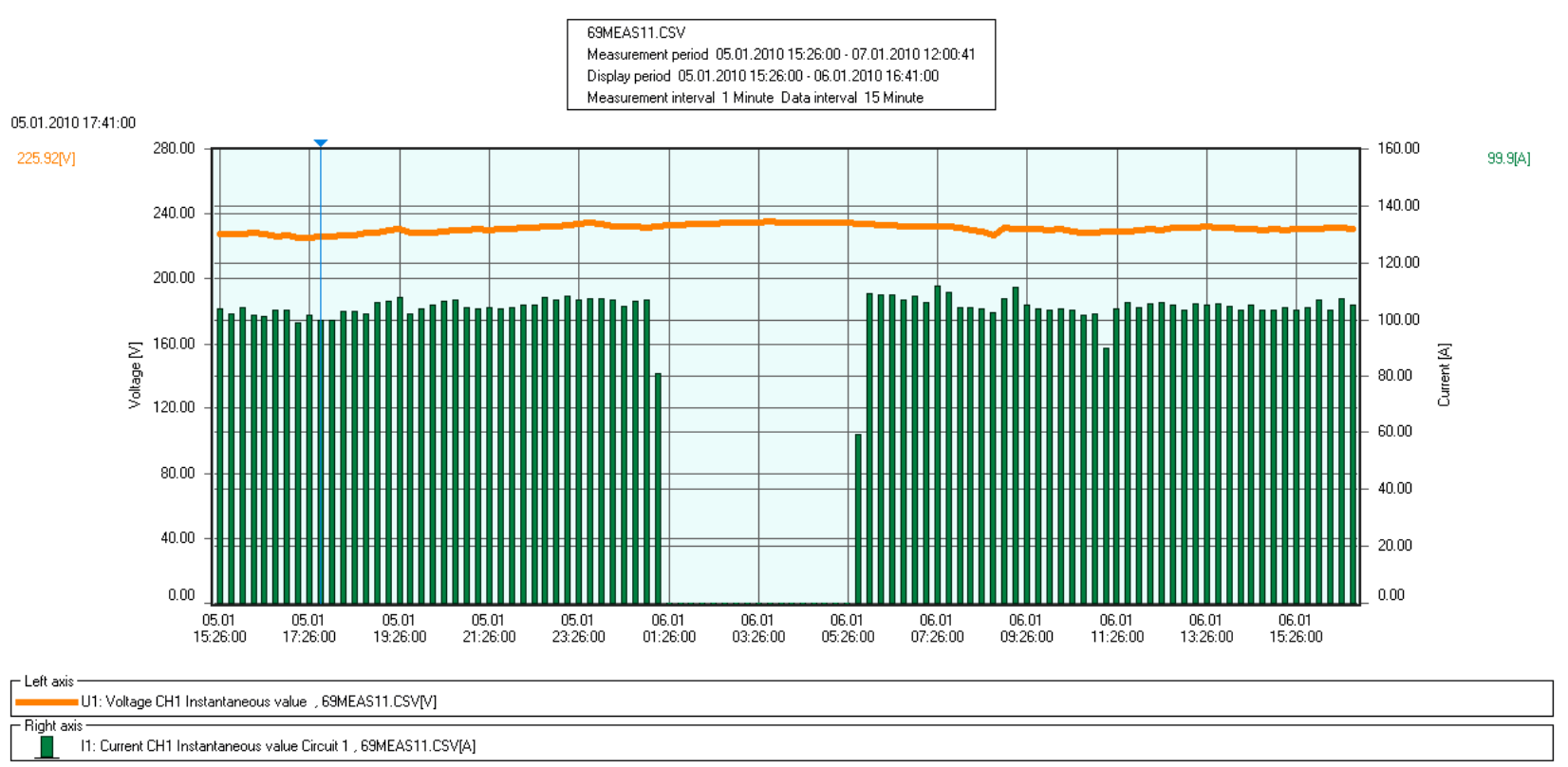

Fig.6. Daily energy consumption of one of the escalators, without motion sensor, at Bahçelievler tunnel station 


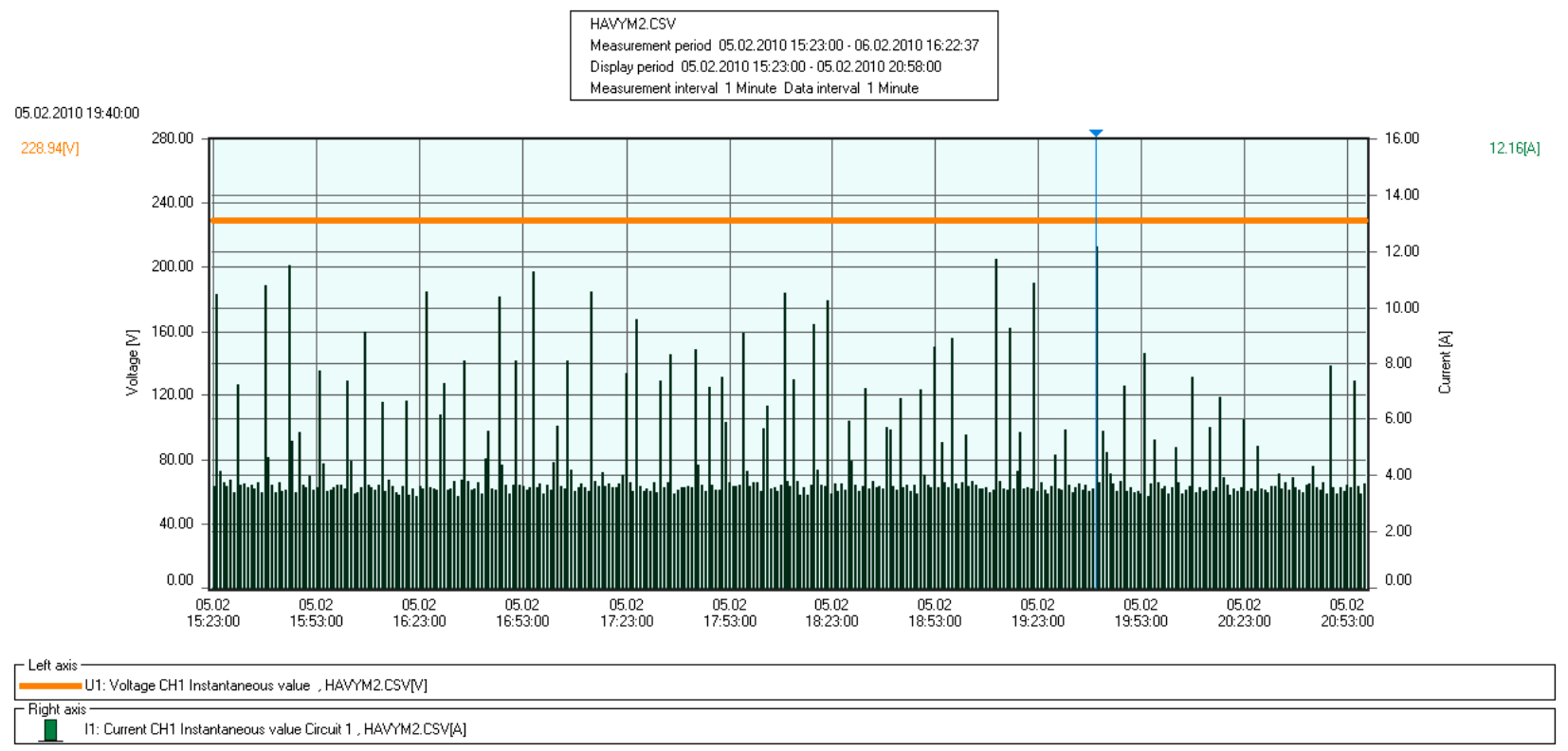

Fig.7. Daily energy consumption of the airport underground station's escalators with the motion sensor.

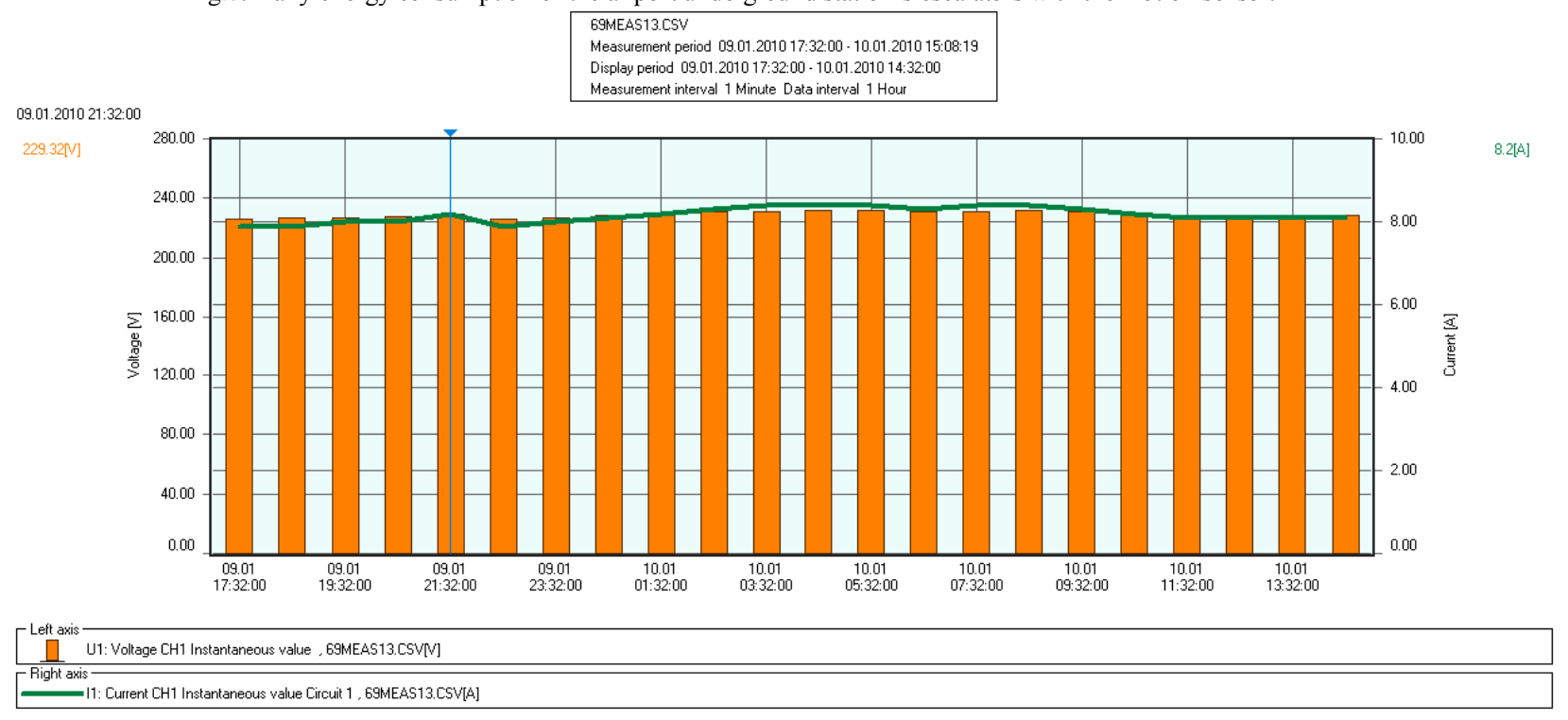

Fig.8. Bahçelievler platform lighting energy consumptions 


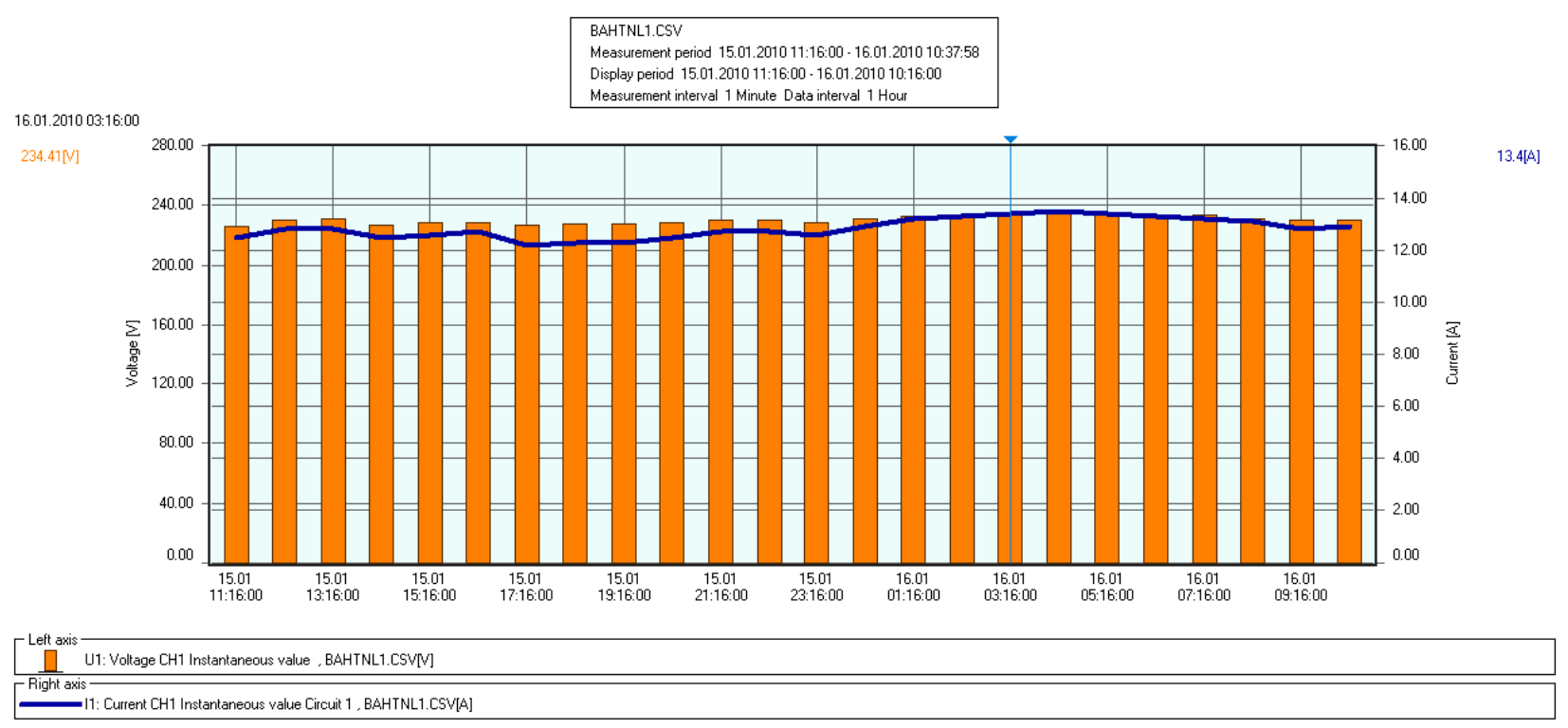

Fig.9. Bahçelievler tunnel lightings energy consumption

Lighting systems at the stations are the second energy consuming category after HVACs. The energy consumptions can be reduced by $28 \%$ applying new technologies like LEDs and smart lighting control systems. The general initiatives are identified based on the latest available technologies to reduce the consumption. Energy savings measures ensuring security, safety and comfort for passengers for the existing and elderly metro stations, like Yenikap1-Atatürk Airport LRT line, can be listed below:

-Lighting management in train stations: Railway stations have limited activity on the platforms, tunnels and outdoor spaces at night, especially after $12 \mathrm{pm}$. The constant light levels make light pollution during the night period. However, the challenge is safety and security problems for passenger and personal when lights off. The energy saving can be provided by using intelligent lighting and sensors in station facilities. The lighting level must be sustained in acceptable minimum values at platforms and tunnels during the night period that trains are at the park area. LED lights usage in stations, information panels, tunnels can provide energy reduction up to $40 \%$ and reducing emission for the environment [42].

-Installing renewable sources on-site: The most common renewable energy integration is a solar PV system. The second renewable energy source is wind turbines. Wind turbines in urbanized areas can generate disturbing noise, and the interfering obstacles must be taken away to produce maximum energy. Renewable energy systems must be evaluated observantly regarding availability and sustainability [41]. Renewable sources can partially feed the non-traction loads like HVAC, lifts, escalators, lightings at stations.

-The use of natural light and Led lightings

-High-performance roof for collecting and reusing rainwater: These identified water conservation measures included both demand-side reduction like the use of water-efficient fixtures and supply-side measures like sewage treatment plant and rainwater harvesting. There exists a water saving potential of around $71 \%$ [43].

-Installing motion sensors for escalators.
-Using the regenerative braking energy of trains: By the use of the braking energy, there is a reduction of the $\mathrm{CO} 2$ emissions. The amount of energy is reduced due to the use of the regenerative brake. There is a reduction potential of approximately $30 \%$ of the energy consumption [23].

-Installing platform screen doors

-Policymaking for sustainable improvement: policy-making team and strategists have to be employed by railway operators. -Building retrofit and energy efficiency projects: Before planning to reduce energy consumption at rail facilities, an energy audit must be executed. Because of significant capital investments of energy saving implementations, a cost analysis requires for determining the payback period.

\section{CONCLUSION}

LEED certification is the most common of the certification developed for the standardization of green buildings for a sustainable future. LEED v4 O + M: Transit certification has been introduced for transportation, which has a large share in emissions, waste and energy consumption, such as living areas. It is a well-known fact that railway transport systems are seen as the most innocent especially in terms of environmental factors and so government-promoted means of transportation. On the other hand, greenhouse gas emissions should be minimized in railway transport for sustainability. The energy consumption of railway transport systems due to elevators, escalators, lighting and HVAC systems with long working hours under negative effects results of their physical structures and usage as public areas are essential amounts. In addition, the use of electric motor as an actuator and the fact that the production of electric energy in many countries is based on fossil fuel makes it necessary to provide energy efficiency in railway systems. 


\section{REFERENCES}

[1] V. Lingaitis, G. Sinkevičius, "Passenger transport by railway: evaluation of economic and social phenomenon", Contemp Issues Business Manage Edu, Procedia - Social and Behavioral Sciences, vol.110, 2014, pp.549-559.

[2] A. González-Gil, R. Palacin, P. Batty, “Optimal energy management of urban rail systems: Key performance indicators" Energ Convers Manage, vol.90, 2015, pp.282-291.

[3] T. Skrucany, M. Kendra, M. Skorupa, J. Grencik, T. Figlus, "Comparison of chosen environmental aspects in individual road transport and railway passenger transport", Procedia Eng vol.192, 2017, pp.806-811.

[4] L. Steg, R. Gifford, "Sustainable transportation and quality of life", J Trans Geogr, vol.13, 2005, pp.59-69.

[5] D. He, B. Ai, K. Guan, J.M Garc'ia-Loygorri, L. Tian, Z. Zhong, A. Hrovat, "Influence of Typical Railway Objects in a mmWave Propagation Channel”, IEEE Trans Veh Technol., vol.67, 2018, pp.2880-2892.

[6] A. González-Gil, R. Palacin, P. Batty, J.P. Powell, "A systems approach to reduce urban rail energy consumption", Energ Convers Manage. vol.80, 2014, pp.509-524.

[7] A. Iliopoulos, K. Kirytopoulos, E. Dermitzakis, "Deciding to Go Green: Challenges and Benefits of the LEED Green Building Rating System", 7th International Symposium and 29th National Conference on Operational Research The contribution of Operational Research, new technologies and innovation in agriculture and tourism, Crete, Greece, June, 2018.

[8] IEA-UIC, Railway Handbook. Energy Consumption and $\mathrm{CO} 2$ emissions focus on passenger rail services, https://uic.org/IMG/pdf/handbook_iea-uic_2017_web3.pdf [accessed 25 March 2019].

[9] https://www.canadianconsultingengineer.com/transportation/leedsystem-designed-transit/1003404787 [accessed 25 March 2019].

[10] D. Pan, L. Zhao, Q. Luo, C. Zhang, Z. Chen, "Study on the Performance Improvement of Urban Rail Transit System", Energy vol. 161, 2018, pp.1154-1171.

[11] LEED in Motion: Transportation, https://readymag.com/usgbc/transportation [accessed 29 April 2019].

[12] Apta Standards Development Program, Recommended Practice. Transit Sustainability Guidelines, Framework for Approaching Sustainability, and Overview of Best Practices. American Public Transportation Association, Washington, DC, USA, 2011.

[13] USGBC Perspective: Understanding Credit Options in LEED v4 $\mathrm{O}+\mathrm{M} ., \quad \mathrm{https} / / / \mathrm{www}$. facilitiesnet.com/green/article/USGBCPerspective-Understanding-Credit-Options-in-LEED-v4-OMFacilities-Management-Green-Feature--17284 [accessed 29 April 2019].

[14] Green Business Certification, Inc. and the U.S. Green Building Council, Measure your green performance, https://arcskoru.com [accessed 29 April 2019].

[15] International Association of Public Transport (UITP), Shaping the future of our cities and towns: introducing FAIR Stations, http://www.uitp.org/news/fairstations [accessed 27 March 2019].

[16] U.S. Green Building Council (USGBC), First LEED Certification for Transit Worldwide Launched, https://www.usgbc.org/articles/firstleed-certification-transit-worldwide-launched [accessed 25 March 2019].

[17] http://www.metro-magazine.com/rail/news/724349/sound-transitstation-achieves-leed-gold-certification [accessed 24 March 2019].

[18] http://www.delhimetrorail.com [accessed 29 April 2019].

[19] https://www.kawneer.com/kawneer/north_america/en/products/project _detail.asp?project=denver_station\&bus=north_america\&pc=Remode 1_Retrofit [accessed 27 March 2019].

[20] http://www.metro-magazine.com/sustainability/news/711211/mta-sfulton-center-receives-leed-silver-certification [accessed 27 March 2019].

[21] http://www.metro-magazine.com/sustainability/news/726571/ill-smetrolink-district-station-earns-leed-gold-certification [accessed 27 March 2019].

[22] https://www.gogreenmetro.com/191/Projects-Planning [accessed 25 March 2019].
[23] L. He, Q. Liang, S. Fang, "Challenges and Innovative Solutions in Urban Rail Transit Network Operations and Management: China's Guangzhou Metro Experience", Urban Rail Transit, 2016, pp.233-45.

[24] A. Opeyemi, MD. Cruz, "Green Sustainability Development for Industry Internet of Things in Railway Transportation Industry", International Conference on Advanced Engineering and Information Technology (ICAEIT), Malaysia, 2017.

[25] U.S. Green Building Council (USGBC), What's new in LEED: LEED v4.1.,

https://www.usgbc.org/articles/whats-new-leed-leed-v41 [accessed 25 March 2019].

[26] American Public Transportation Association, Sustainability \& Public Transportation Workshop, San Francisco, CA, 2013. http://www.apta.com/mc/sustainability/previous/2013/presentations/Pr esentations/Shatzkin-LEED-Silver-for-Light-Rail-Stations.pdf [accessed 24 April 2019].

[27] The Metropolitan Transportation Authority, Blue Ribbon Commission on Sustainability Renewable Energy Task Report, http://web.mta.info/sustainability/pdf/MTA\%20Renewable\%20Energ y\%20Report\%2010\%2029\%2008.pdf/ [accessed 17 May 2019].

[28] http://www.railway-technology.com/features/smart-railway-stationscities-creating-living-transport-hubs/ [accessed 24 March 2019].

[29] S. Rzepnicka, D. Załuski, "Innovative_Railway_Stations". IOP Conf. Series: Materials Science and Engineering 2017.

[30] https://www.smartrailworld.com/9-innovations-that-are-shaping-thefuture-of-your-railway-station/ [accessed 27 March 2019].

[31] https://newatlas.com/tbox-concept-would-capture-wind-energy-fromspeeding-trains/18272/ [accessed 26 March 2019].

[32] UIC (Union Internationale des Chemins de fer) report, Study on Nontraction Energy Consumption and Related $\mathrm{CO}_{2}$ emissions from the European Railway Sector, Copenhagen and Berlin. https://uic.org/IMG/pdf/uic_nontraction_energy_study_final_report_ju ne_2012.pdf/ [accessed 20 March 2019].

[33] https://www.adb.org/sites/default/files/publication/173696/energyintelligent-railway-station.pdf / [accessed 26 March 2019].

[34] B. Kılı̨, S. Tuna, B. Yagcitekin, S. Özenç, "Energy efficiency analysis of lighting systems at fixed facilities on light metro systems: a case study". 5th International Ege Energy Symposium and Exhibition (IEESE-5), Turkey, 2010.

[35] UIC (Union Internationale des Chemins de fer) report (2016). Technologies and potential developments for energy efficiency and $\mathrm{CO} 2$ reductions in rail systems https://uic.org/IMG/pdf/_27_technologies_and_potential_development s_for_energy_efficiency_and_co2_reductions_in_rail_systems._uic_in _colaboration.pdf / [accessed 24 March 2019].

[36] P.C. Leung, E.W.M. Lee, "Estimation of electrical power consumption in subway station design by intelligent approach", Appl Energy, vol.101, 2013, pp.634-643.

[37] S. Su, T. Tang, Y. Wang, "Evaluation of strategies to reducing traction energy consumption of metro systems using an optimal train control simulation model", Energies, vol.9, 2016, pp.105-124.

[38] The metro Istanbul annual activity report, http://www.ibb.gov.tr/enUS/Documents/annual_reports/IMM_ANNUAL\%20REPORT_2015.p df/ [accessed 24 April 2019].

[39] Istanbul Metropolitan Municipality, www.metroistanbul/ [accessed 27 March 2019].

[40] J. Liu, B. Lin, Y. Zhang, Q. Zhu, Y. Zhu, "Case study - how could we optimize the energy-efficient design for an extra-large railway station with a comprehensive simulation? Building Simulation”, 2011-12th Conference of International Building Performance Simulation Association, Sydney, Australia, 2011.

[41] K. Fu, Z. Deng, "Current situation of energy consumption in Guangzhou railway station and analysis on the potential of energy conservation", J Sustain Dev, vol.2, 2009, pp.117-120.

[42] Energy efficiency and reliability solutions for rail operations and facilities (2014). $\quad$ A https://www.ctcase.org/reports/railenergy.pdf/ [accessed 29 April 2019].

[43] Suzuki T. A Vision of future railway station, http://www.ejrcf.or.jp/jrtr/jrtr06/pdf/f06_suz.pdf / [accessed 29 April 2019]. 


\section{BIOGRAPHIES}

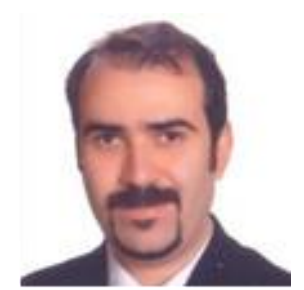

ERKAN DURSUN was born in 1977 in Kayseri, Turkey. He received $\mathrm{PhD}$ from Marmara University. His $\mathrm{PhD}$ thesis about Distributed Generation (DG), which consist of the photovoltaic/wind/fuel cell hybrid power system. The quality of $\mathrm{PhD}$ thesis results is demonstrated by the fact that a paper describing the core contribution of the thesis has been accepted to many scientific journals and conferences. His papers have received more than 400 citations in SCI database of Thomson Reuters. He has been working on power system, renewable energy systems and smart grid for 12 years. He worked as a researcher at European Commission, JRC Institute for Energy and Transport (IET) from 2012 to 2013. He became an Assistant Professor at Marmara University, Faculty of Technology, Department of Electrical and Electronics Engineering in 2013. He is a member of IEEE.

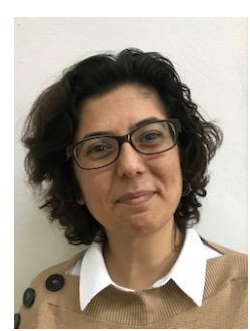

SECIL VARBAK NESE received the B.S. degree in Electrical Education from Kocaeli University, Kocaeli, Turkey, in 2004, the M.S. degree in Electrical Education from the Afyon Kocatepe University, Afyonkarahisar, Turkey, in 2008, and the Ph.D. degree in Electrical Education from the Marmara University, Istanbul, Turkey, in 2015. She is currently an Assistant Professor Dr. at Electrical-Electronics Engineering in Marmara University, Istanbul, Turkey. Her current research interests include power systems, renewable energy.

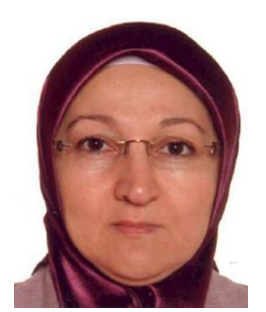

BEYHAN KILIC was born in Yozgat, Turkey. She completed B.Sc. at the Department of Electrical Engineering, Yildiz Technical University and $\mathrm{Ph} . \mathrm{D}$. at the same department of Yildiz Technical University respectively in 1985 and 1998. She worked at Istanbul Metropolitan Municipality Energy Department 20072009. She was assigned to Istanbul Metro Co. for three years. She is currently as Research Assistant at the Electrical Engineering Department of Yildiz Technical University. Her research areas are: railway systems, integration of renewable energy to railway systems, energy management and smart grid applications in railway systems. 